\title{
NILAI PENTING DAN ESTIMASI NILAI EKONOMI \\ SIMPANAN KARBON VEGETASI MANGROVE DI KEMA, SULAWESI UTARA
}

\author{
IMPORTANT VALUE AND ECONOMIC VALUE ESTIMATION \\ OF CARBON STORAGE OF MANGROVE VEGETATION IN KEMA, NORTH SULAWESI
}

\author{
Terry Louise Kepel, Devi Dwiyanti Suryono, Restu NurAfi Ati, \\ Hadiwijaya Lesmana Salim dan Andreas Albertino Hutahaean \\ Pusat Riset Kelautan, Badan Riset dan Sumberdaya Manusia Kelautan dan Perikanan, \\ Kementerian Kelautan dan Perikanan Jl. Pasir Putih I, Ancol Timur-Jakarta Utara \\ Telp:+62 2164711583 , Fax: +62 2164711654 . \\ e-mail : kepel@kkp.go.id
}

Diterima tanggal: 10 Februari 2017 ; diterima seletah perbaikan: 27 Maret 2017; Disetujui tanggal: 20 April 2017

\begin{abstract}
ABSTRAK
Ekosistem mangrove berperan penting tidak hanya bagi sektor perikanan, tapi juga dalam mitigasi perubahan iklim sebagai penyerap dan penyimpan karbon. Metode perhitungan nilai penting ekosistem mangrove tidak hanya memperhatikan aspek ekologi tetapi juga aspek ekonomi dari setiap jasa ekosistem yang disediakannya. Tujuan penelitian ini untuk mendapatkan informasi tentang nilai penting simpanan karbon dan estimasi nilai ekonomi simpanan karbon vegetasi mangrove di Kema, Kabupaten Minahasa Utara, Sulawesi Utara. Pengambilan data dilakukan di tujuh stasiun dengan menggunakan metode transek kuadrat seluas $100 \mathrm{~m}^{2}$ yang diletakkan secara vertikal terhadap garis pantai. Pengukuran DBH digunakan untuk mengetahui biomassa dan simpanan karbon, sedangkan estimasi nilai ekonomi simpanan karbon menggunakan pendekatan harga dari pasar bebas dan pasar wajib Clean Development Mechanism (CDM). Sebanyak 8 spesies vegetasi mangrove yang teridentifikasi, yaitu Avicennia alba, Avicennia officinalis, Bruguiera gymnorrhiza, Ceriops tagal, Lumnitzera littorea, Rhizophora apiculata, Rhizophora mucronata dan Sonneratia alba. Analisis INP menunjukkan S. alba dan R. mucronata memiliki peran yang penting dalam keberlangsungan ekosistem ini. Nilai rerata simpanan karbon di kawasan Kema sebesar 133,76 $\pm 25,70 \mathrm{MgCha}^{-1}$. Nilai rerata estimasi ekonomi simpanan karbon yang dihasilkan adalah sebesar Rp. 6.955.123.566 (pasar bebas) atau US\$ 519.310,56 dan Rp. 18.176.056.252 (CDM)atau US\$ 1.357.131,6 untuk simpanan rerata karbon sebesar 23.397 $\pm 4.495 \mathrm{MgC}\left(85.865,72 \pm 16.496,15 \mathrm{Mg} \mathrm{CO}_{2 \mathrm{e}}\right)$ pada luasan mangrove sebesar 174,92 ha. Nilai ekologi dan ekonomi yang dihasilkan dari penelitian ini, dapat dijadikan sebagai informasi awal perumusan kebijakan pengelolaan ekosistem mangrove yang lestari dan berkelanjutan.
\end{abstract}

Kata kunci: Nilai penting, nilai ekonomi, simpanan karbon, mangrove, Kema.

\section{ABSTRACT}

Mangrove ecosystem has an important role for the fisheries sector, as well as contributing to climate change mitigation as carbon sinks. Method of calculating the important value of the mangrove ecosystem not only consider the ecological aspect but also includes the economic aspect of each ecosystem services provided. The purpose of this study were to obtain information on the important values, carbon storage in vegetation and estimated economic value of carbon storage of mangrove in Kema, North Minahasa Regency, North Sulawesi. Data were collected at seven stations using a 100 m2 transect method placed perpendicularly to the shoreline. DBH measurements was done to determine the biomass and carbon storage, while the estimated economic value of carbon storage using the pricing approach of the carbon free market and regulated market -CDM. There were eight species identified: Avicennia alba, Avicennia officinalis, Bruguiera gymnorrhiza, Ceriops tagal, Lumnitzera littorea, Rhizophora apiculata, Rhizophora mucronata and Sonneratia alba. Important value index analysis showed $S$. alba and R. mucronata have an important role for the sustainability of this ecosystem. The average value of carbon stocks in Kema was 133,76 $\pm 25,76 \mathrm{MgCha}^{-1}$. The economic value based on voluntary market was Rp. 6,955,123,566 or US\$ 519,310.56 smaller than Clean Development Mechanism which was Rp. 18,176,056,252 or US\$ 1,357,131.6 for $23.397 \mathrm{MgCha}^{-1}$ of carbon stocks with covering mangrove area of 174,92 ha. Ecological and economic value generated from this study can be used as initial information for policy formulation for sustainable mangrove ecosystem management.

Keywords: Important value, economic value, carbon, mangrove, Kema.

Nilai Penting dan Estimasi Nilai Ekonomi Simpanan Karbon Vegetasi Mangrove di Kema, Sulawesi Utara - Terry Louise Kepel, Devi Dwiyanti Suryono, Restu NurAfi Ati, 


\section{PENDAHULUAN}

Kecamatan Kema merupakan bagian dari kawasan Teluk Tomini, teluk terbesar kedua di Indonesia setelah Teluk Cendrawasih. Kawasan teluk Tomini mencakup ekosistem terumbu karang, padang lamun dan mangrove serta pantai wisata dan pelabuhan laut (Pramudji, 2004). Wilayah Kecamatan Kema terletak di Kabupaten Minahasa Utara yang berbatasan dengan Kota Bitung dan Kota Manado. Daerah ini merupakan salah satu daerah yang memiliki potensi kekayaan alam yang beragam, diantaranya adalah ekosistem mangrove.

Ekosistem mangrove selain berfungsi ekologis bagi sektor perikanan, juga berfungsi sebagai pelindung garis pantai, mencegah abrasi air laut, habitat aneka biota perairan, serta sebagai pengatur iklim mikro. Manfaat penting lain ekosistem mangrove adalah mampu menyerap karbon dioksida $\left(\mathrm{CO}_{2}\right)$ dari udara. Penyerapan karbon dioksida berhubungan erat dengan biomassa pohon. Pohon melalui proses fotosintesis menyerap $\mathrm{CO}_{2}$ dan mengubahnya menjadi karbon organik (karbohidrat) dan menyimpannya dalam biomassa tubuh pohon. Beberapa tahun ini potensi penyimpanan karbon di ekosistem mangrove mulai mendapat perhatian sebagai salah satu jasa ekosistem yang berperan dalam mitigasi perubahan iklim (Bouillon et al., 2008; Alongi 2014; Murdiyarso et al., 2015; Alongi et al., 2015).

Penentuan nilai penting ekosistem selain dapat dilakukan dengan pendekatan ekologi juga melalui valuasi ekonomi dari setiap fungsi komponen biotik dan abiotik pada ekosistem tersebut. Perhitungan nilai ekonomi mangrove di Indonesia sudah banyak dilakukan dengan pendekatan manfaat langsung dan tidak langsung, antara lain dilakukan oleh Suzana et.al. (2011), Saprudin dan Halidah (2012), serta Nahib (2011). Manfaat langsung meliputi nilai kayu sebagai bahan bangunan dan kayu bakar, nilai perikanan ekonomis (ikan, udang, kepiting), nilai daun dan buah mangrove/nipah. Adapun manfaat tidak langsung meliputi fungsi mangrove sebagai penahan abrasi yang dikalkulasi berdasarkan replacement cost bangunan pemecah ombak (breakwater) serta manfaat pilihan yang menghitung manfaat keanekaragaman hayati ekosistem mangrove (Suzana et.al., 2011). Menurut Suzana et al.(2011), jika hutan mangrove dipertahankan maka keuntungan akan 39,8 kali lebih besar dibandingkan mengeksploitasi sumberdaya alam hutan mangrove.
Sebagai salah satu jasa ekosistem dari mangrove, nilai penyimpanan karbon baik pada biomassa maupun substrat sebagai tempat tumbuh mulai diperhitungkan dalam skema pembayaran jasa ekosistem atau Payment for Ecosystem Services (PES) sebagai karbon kredit (Pendleton et al., 2012; Siikamäki et al., 2012). Penilaian ekonomi pada simpanan karbon untuk perubahan iklim telah dilakukan di daerah Uni Eropa dan skala global (Gren, 2015). Valuasi ekonomi merupakan salah satu upaya dalam menjaga ekosistem tersebut (Ullman et al., 2013; Salem \& Mercer, 2012; Gren, 2015).

Hasil penelitian Jerath et al. (2016) mengestimasi nilai simpanan karbon total per unit area ekosistem mangrove di Everglades-Florida sebesar US\$ 13.859/ ha $-23.728 /$ ha. Sedangkan di Indonesia, estimasi nilai ekonomi terhadap simpanan karbon belum banyak dilakukan.

Tujuan tulisan ini adalah untuk mengestimasi: nilai penting ekologis, simpanan karbon pada vegetasi, serta nilai ekonomi simpanan karbon mangrove di Kema. Gambaran estimasi nilai ekonomi dalam tulisan ini masih merupakan gambaran awal tanpa memperhitungkan faktor-faktor yang lain seperti biaya pemeliharaan dan pengelolaan ekosistem mangrove apabila digunakan dalam perdagangan karbon.

\section{BAHAN DAN METODE}

\section{Lokasi Pengambilan Data}

Penelitian dilakukan pada bulan Juli 2015 di pesisir Kecamatan Kema Kabupaten Minahasa Utara. Terdapat tujuh stasiun pengukuran dan pengambilan sampel yang tersebar dari Selatan ke Utara, mulai dari wilayah muara Kuala Mangket sampai ke Tasikoki -Kema.

\section{Metode Pengumpulan Data dan Sampel}

Penentuan stasiun pengambilan data dilakukan sebelum pengambilan data di lapangan dengan menggunakan software arcGIS 10. Pengumpulan data mangrove dilakukan dalam transek kuadrat seluas $100 \mathrm{~m}^{2}$ sebanyak lima buah yang diletakkan pada garis vertikal yang tegak lurus garis pantai. Jarak antar transek kuadrat sebesar 10 meter (Bengen, 2003; Sutaryo, 2009).

Identifikasi spesies mangrove dilakukan berdasarkan cirimorfologi akar, daun, buah dan bunga. Penghitungan jumlah tegakan mangrove dilakukan pada mangrove 
yang dikategorikan sebagai pohon atau yang tingginya melebihi 1,3 meter (Sutaryo, 2009). Mangrove yang ada di dalam transek kemudian diidentifikasi, dihitung jumlah tegakan pohon, jumlah anakan, jumlah semai serta pengukuran diameter breast high (dbh) pohon. Analisis konsentrasi karbon vegetasi dan sedimen dilakukan di laboratorium Bioteknologi Tanah, IPB dengan menggunakan alat CHNS Analyzer.

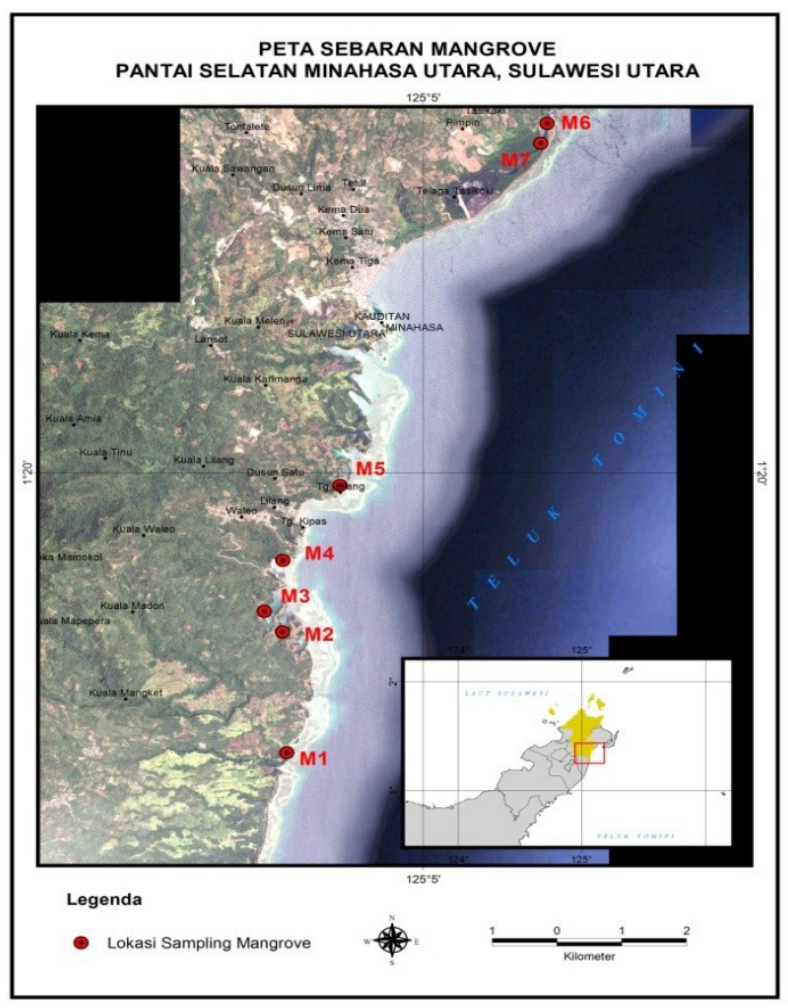

Gambar 1. Peta Studi

\section{Analisis Data}

Figure 1. Map of study sites.

Kondisi ekosistem mangrove direpresentasikan dengan kondisi kerapatan spesies (Di), kerapatan relatif spesies (RDi), frekuensi spesies (Fi), frekuensi relatif spesies (RFi) dan nilai penting spesies (INP) mangrove yang ada di lokasi. Indeks Nilai Penting (INP) menggambarkan kedudukan ekologis suatu spesies dalam komunitas dengan melihat dominasi suatu spesies terhadap spesies lainnya. Nilai indeks ini berkisar antara 0 - 300 atau 1-3.

Perhitungan jumlah simpanan karbon pada vegetasi mangrove dilakukan dengan melakukan estimasi terhadap besaran biomassa. Perhitungan biomassa menggunakan persamaan matematis yang sudah banyak dikembangkan baik spesifik terhadap spesies maupun persamaan umum yang digunakan untuk semua spesies. Kapasitas penyimpanan karbon di ekosistem ini dihitung berdasarkan hasil analisis kandungan karbon pada batang mangrove dikalikan dengan biomassa. Nilai kandungan karbon pada masing-masing spesies yang ada berbeda-beda dengan kisaran $42-45 \%$. Pada spesies yang tidak diukur nilai karbonnya maka dihitung sebagai $50 \%$.

Estimasi nilai ekonomi simpanan karbon yang dipakai di dunia saat ini beragam, karena tergantung pada mekanisme pasar yang diterapkan (DNPI, 2013). Jerath et al. (2016) mengestimasi nilai ekonomi karbon di ekosistem mangrove Everglades, Florida Selatan dengan menggunakan nilai social costs of carbon (SSC), marginal abatement costs (MACs) dan harga pasar dalam hal ini adalah harga yang diatur oleh program pengurangan emisi gas di Amerika Regional Greenhouse Gas Initiative (RGGI). Dalam penelitian ini digunakan dua harga karbon, yaitu harga yang berlaku di pasar sukarela (voluntary market) dan pasar wajib (regulated market) Clean Development Mechanism (CDM) masing-masing sebesar Rp 81.000/ $\mathrm{tCO}_{2 \mathrm{e}}$ dan $\mathrm{Rp} 211.680 / \mathrm{tCO}_{2 \mathrm{e}}$. Harga yang digunakan ini diambil dari data global market tahun 2010 (Ullman et al., 2012). Harga konversi US\$ 1 yang digunakan adalah sebesar $\mathrm{Rp} 13.500$.

\section{HASIL DAN PEMBAHASAN}

\section{Luasan Ekosistem Mangrove Kecamatan Kema}

Kecamatan Kema adalah salah satu dari 10 kecamatan di Kabupaten Minahasa Utara. Sebelum menjadi kecamatan Kema, desa-desa di wilayah kecamatan ini adalah bagian dari kecamatan Kauditan. Sejak tahun 2004, beberapa desa di wilayah pesisir Kecamatan Kauditan menjadi kecamatan Kema. Dengan demikian, sejak saat itu kecamatan Kauditan sudah tidak lagi memiliki kawasan pesisir.

Berdasarkan hasil analisis citra Landsat tahun 20012007 wilayah pesisir bagian Selatan Sulawesi Utara didapatkan bahwa terjadi fluktuasi luasan ekosistem mangrove (Gambar 2). Total luasan mangrove pada tahun 2007 sekitar 1.370,495 ha atau meningkat sebanyak 5,5\% dari tahun 2001. Peningkatan luasan ini terjadi di 4 kecamatan, salah satunya di kecamatan Kauditan. Saat ini kecamatan Kauditan menjadi kecamatan Kema. Peningkatan luasan ekosistem mangrove di kecamatan ini sebesar 5,468 ha, yakni dari 144,896 ha menjadi 150,364 ha. Selanjutnya hasil pengukuran luasan ekosistem mangrove di Kema dengan citra landsat tahun 2015 adalah sebesar 174,92 ha. Dengan demikian, selama delapan tahun sejak tahun 2007 kembali terjadi peningkatan dengan luas sebesar 24,55 ha. 

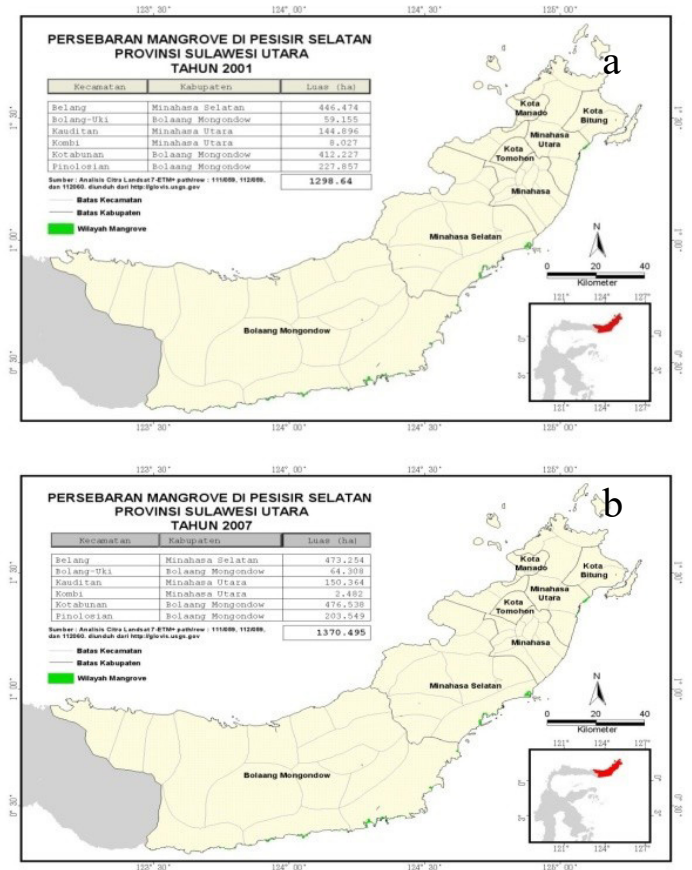

Gambar 2. Kawasan ekosistem mangrove berdasarkan analisis Citra Landsat pada tahun 2001 (a) dan 2007 (b).

Figure 2. Mangrove ecosystem area based on Landsat Image analysis in 2001 (a) and 2007 (b).

\section{Kondisi Ekologi Ekosistem Mangrove}

Berdasarkan hasil penelitian diperoleh delapan spesies mangrove yaitu Avicennia alba, Avicennia officinalis, Bruguiera gymnorrhiza, Ceriops tagal, Lumnitzera littorea, Rhizophora apiculata, Rhizophora mucronata dan Sonneratia alba. Spesies yang dijumpai pada setiap stasiun adalah $R$. mucronata dengan tegakan yang tumbuh baik di dekat garis pantai (seaward) maupun ke arah daratan (landward). S. alba juga dijumpai di hampir semua stasiun kecuali stasiun M4 yang didominasi oleh R.mucronata. Spesies C. tagal hanya dijumpai di stasiun M6 dan L. Littorea di M7. Hasil pengamatan menunjukkan tidak adanya zonasi vertikal (dari laut ke daratan) yang jelas dari komunitas mangrove yang ada. Hal ini dapat disebabkan oleh kondisi fisik perairan seperti pasang surut, sedimen dan salinitas yang cenderung seragam. Stasiun M2, M3, M6 dan M7 memiliki kerapatan vegetasi yang tinggi (> 1500 individu/ha), stasiun M5 memiliki tingkat kerapatan sedang serta stasiun M1 dan M4 memiliki kerapatan yang rendah ( $<1000$ individu/ha) (Tabel 1.).

Besaran diameter dari setiap tegakan pohon bervariasi antar spesies yaitu sebesar 3,18-63 cm (Tabel 2). Tegakan $S$. alba memiliki rerata diameter pohon yang lebih besar dibandingkan dengan spesies yang lain yaitu $18,51 \mathrm{~cm}$, sedangkan $L$. littorea memiliki diameter pohon yang paling kecil sebesar $3,18 \mathrm{~cm}$.
Tabel 1. Kondisi mangrove di lokasi studi

Table 1. Condition of mangrove at study site

\begin{tabular}{llll}
\hline Stasiun & $\begin{array}{l}\text { Kerapatan } \\
\text { (ind/ha) }\end{array}$ & $\begin{array}{l}\text { Rerata } \\
\text { DBH }\end{array}$ & $\begin{array}{l}\text { Spesies } \\
\text { Dominan }\end{array}$ \\
\hline M1 & 900 & 29,82 & RM, SA \\
M2 & 1775 & 12,54 & RM, SA \\
M3 & 2500 & 15,06 & RM, SA \\
M4 & 760 & 11,78 & RM, SA \\
M5 & 1180 & 15,87 & SA \\
M6 & 1967 & 16,24 & CT \\
M7 & 1780 & 11,49 & AA \\
\hline
\end{tabular}

L. littorea adalah salah satu spesies mangrove yang masuk dalam IUCN Red List of Threatened Spesies (Ellison et al., 2010). Dalam kondisi lingkungan yang optimal, L. Littorea dapat bertumbuh sampai ketinggian $25 \mathrm{~m}$ (80 ft). Pada kondisi dengan keterbatasan nutrien, spesies ini biasanya membentuk semak (shrub) atau pohon dengan ukuran kecil ( $<6$ meter) (Ellison et al, 2010).

Meskipun hanya terdapat di satu stasiun, diameter $C$. tagal di kawasan mangrove Kema mencapai 27,39 cm. Ceriops tagal adalah spesies mangrove yang dapat bertahan pada kondisi salinitas yang ekstrim. Salinitas maksimum yang dapat ditoleransi oleh spesies ini adalah 45 ppt dengan salinitas optimum sebesar 0 - 15 ppt (Duke et al., 2010).

Berdasarkan data besaran rerata diameter mangrove di setiap stasiun, terlihat bahwa stasiun M1 memiliki nilai diameter tertinggi disusul oleh stasiun M6, M5, M3, M2, M4 dan yang terkecil terdapat di stasiun M7. Hal ini mengindikasikan bahwa stasiun M1 adalah daerah mangrove yang relatif alami dan tidak mengalami tekanan antropogenik dibandingkan dengan lokasi lain, karena masih memiliki mangrove dengan ukuran diameter yang besar. Relatif terjaganya komunitas mangrove di kawasan ini kemungkinan disebabkan oleh jauhnya dari lokasi pemukiman penduduk dibandingkan dengan beberapa lokasi lain, seperti stasiun M4 dan M5 yang dekat dengan Desa Waleo dan Lilang serta stasiun M6 dan M7 yang dekat dengan Desa Pimpin dan Tasikoki.

Hasil analisis struktur komunitas terlihat bahwa spesies R. mucronata dan S. alba memiliki tingkat kerapatan relatif yang lebih tinggi dibandingkan spesies yang lain, sedangkan 4 spesies lainnya, yaitu $A$. alba, $B$. gymnorrhiza, $C$. Tagal dan $R$. apiculata memiliki kerapatan relatif yang lebih rendah. Tingkat kerapatan 
yang paling rendah adalah pada $A$. officinalis dan $L$. littorea (Tabel 3). Spesies L. littorea hanya ditemukan satu tegakan di dalam transek pengukuran. Daerah ini kemungkinan mempunyai tegakan $L$. littorea yang lebih banyak dibandingkan dengan tegakan terukur atau yang berada di dalam transek pengambilan data. Selain tingkat kerapatan relatif spesies yang tinggi, $R$. mucronata dan $S$. alba juga memiliki frekuensi relatif yang paling tinggi.

Hasil analisis penutupan relatif spesies (RCi) menunjukkan bahwa penutupan $S$. alba mendominasi spesies yang lain karena mencapai $62 \%$. R. mucronata memiliki nilai penutupan relatif spesies sebesar 26,34\%. Hal ini diduga karena tingginya distribusi relatif spesies dan besarnya diameter tegakan yang terukur.

Analisis Indeks Nilai Penting (INP) menunjukkan peranan suatu spesies mangrove pada ekosistem tersebut (Bengen, 2002). Makin besar INP maka makin besar pula peranan atau nilai ekologis dari suatu spesies. Hasil analisis INP menunjukkan bahwa $S$. alba dan $R$. mucronata memiliki peran yang penting dalam keberlangsungan ekosistem tersebut

Kawasan mangrove Kema didominasi oleh spesies $S$. alba dan $R$. mucronata. Berdasarkan kondisi fisik ekosistem yang ada, kedua spesies dapat berkembang dengan baik. Hal ini terlihat dari rerata diameter batang terukur yang relatif lebih besar dibandingkan dengan spesies yang lain (Tabel 2).

\section{Biomassa dan Simpanan Karbon}

Hasil perhitungan biomas dan karbon di vegetasi bervariasi antara 88,24 - 631,46 $\mathrm{Mgha}^{-1}$ dan 38,32 - 261,85 $\mathrm{MgCha}^{-1}$ (Gambar 3). Nilai rerata simpanan

Tabel 2. Diameter masing-masing spesies

Table 2. Stand diameter of each species

\begin{tabular}{llll}
\hline \multirow{2}{*}{ Spesies } & \multicolumn{3}{c}{ Diameter (cm) } \\
\cline { 2 - 4 } & Min & Maks & Rerata \\
\hline A. alba & 3,18 & 14,01 & 6,86 \\
A. officinalis & 5,41 & 11,15 & 8,28 \\
B. gymnorrhiza & 3,18 & 19,75 & 8,07 \\
C. tagal & 3,50 & 27,39 & 7,17 \\
L. littorea & 3,18 & 3,18 & 3,18 \\
R. apiculata & 3,82 & 31,85 & 11,00 \\
R. mucronata & 3,50 & 31,85 & 12,21 \\
S. alba & 3,50 & 63,06 & 18,51 \\
\hline
\end{tabular}

Tabel 3. Struktur Masyarakat Mangrove

Table 3. Mangrove Community Structure

\begin{tabular}{lllll}
\hline Spesies & RDi & Rfi & Rci & INP \\
\hline A.alba & 11.20 & 8.06 & 2.76 & 22.03 \\
A. officinalis & 1.21 & 3.23 & 0.29 & 4.72 \\
B. gymnorrhiza & 9.54 & 14.52 & 3.19 & 27.25 \\
C. tagal & 8.17 & 3.23 & 1.92 & 13.32 \\
L. littorea & 0.61 & 1.61 & 0.01 & 2.23 \\
R. apiculata & 9.69 & 4.84 & 3.21 & 17.74 \\
R. mucronata & 30.79 & 37.10 & 26.34 & 94.23 \\
S. alba & 28.79 & 27.42 & 62.27 & 118.49 \\
Total & 100 & 100 & 100 & 300 \\
\hline
\end{tabular}

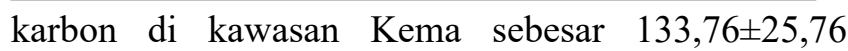
$\mathrm{MgCha}^{-1}$. Nilai terendah di stasiun M7 dan tertinggi di M1. Dari hasil analisis diperoleh bahwa biomassa dan simpanan karbon di bagian Selatan cenderung lebih tinggi daripada bagian Utara.

Stasiun M1 dan M3 memiliki nilai simpanan karbon yang tinggi karena adanya dominasi dari spesies $R$. mucronata dan $S$. alba yang secara rerata memiliki diameter tegakan yang tinggi. Hasil analisis hubungan antara nilai biomas dan karbon lebih dipengaruhi oleh rerata besaran diameter pohon dibandingkan dengan kerapatan pohon per satuan luas (Gambar 4).

Nilai rerata simpanan karbon di Kema relatif lebih tinggi dibandingkan dengan beberapa simpanan karbon vegetasi yang pernah diteliti, diantaranya simpanan karbon mangrove di Teluk Miskam berkisar antara 2,5 - 55,33 $\mathrm{Mg} \mathrm{C}$ ha $^{-1}$ (Ati dkk, 2014), Pulau Kemujan - Karimunjawa yang sebesar $91,31 \mathrm{MgCha}^{-1}$ (Cahyaningrum et al., 2014; Hartoko et al,, 2015). Namun ada beberapa ekosistem mangrove yang memiliki simpanan karbon lebih tinggi dibandingkan Kema, seperti ekosistem mangrove Ciasem-Jawa Barat yang didominasi oleh $A$. marina memiliki simpanan karbon sebesar 182,5 $\mathrm{MgCha}^{-1}$ (Dharmawan \& Siregar, 2008). Simpanan karbon yang lebih tinggi juga dijumpai di Bintuni, Timika dan Sembilang yaitu di atas $200 \mathrm{MgCha}^{-1}$ (Murdiyarso et al., 2015).

Berdasarkan hasil analisis nilai biomas yang dihitung yaitu bagian atas dan bawah terlihat bahwa kontribusi bagian bawah dari pohon mangrove berkisar antara 29 - 45\% dibandingkan dengan bagian atas (59-71\%) dengan beda proporsi terbesar di stasiun M4 (Gambar 3). Hal ini sesuai dengan Kauffman \& Donato (2012) bahwa semua komponen kolam karbon (carbon pool) di bagian atas, biomassa dari pohon hidup (living biomass) menyumbang kontribusi karbon yang paling besar. 


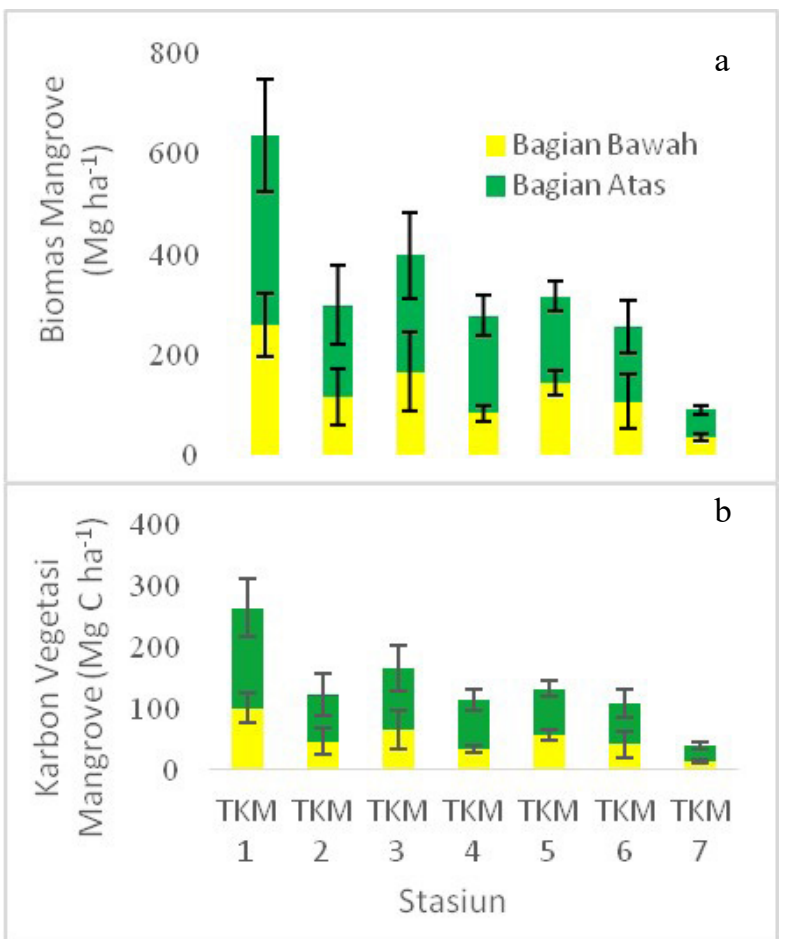

Gambar 3. Biomassa (a) dan penyimpanan karbon (b) vegetasi mangrove di Kema dengan standar error (SE)

Figure 3. Biomass (a) and carbon storage (b) mangrove vegetation in Kema with standard error (SE)

\section{Valuasi Nilai Ekonomi Simpanan Karbon}

Berdasarkan nilai biomassa dan karbon pada setiap stasiun didapatkan nilai rerata untuk kawasan mangrove di Kecamatan Kema yaitu sebesar $321,91 \pm 62,35 \mathrm{Mg} \mathrm{ha}^{-1}$ dan karbon $133,76 \pm 25,70 \mathrm{Mg}$ $\mathrm{C}$ ha $^{-1}$. Merujuk pada luasan ekosistem mangrove di Kema sebesar 174,92 ha, maka nilai total biomassa sebesar $56.308 \pm 10.906 \mathrm{Mg}$ dan simpanan karbon sebesar 23.397 $\pm 4.495 \mathrm{MgC}$. Besaran simpanan karbon tersebut setara dengan $490,89 \pm 94,31 \mathrm{Mg} \mathrm{CO}_{2 \mathrm{e}} \mathrm{ha}^{-1}$ atau $85.865,72 \pm 16.496,15 \mathrm{MgCO}_{2 \mathrm{e}}$ pada luasan 174,92 ha. Nilai ini kemudian dikalikan dengan harga karbon per megagram (ton) $\mathrm{CO}_{2 \mathrm{e}}$ (Tabel 4).

Tabel 4. Nilai Ekonomi Karbon Vegetasi Mangrove (Rp per $\mathrm{MgCO}_{2 \mathrm{e}}$ )dengan perbandingan harga pasar karbon bebas dan Pasar Wajib- CDM

Table 4. Economic Value of Mangrove Vegetation Carbon (Rp per $\mathrm{MgCO}_{22}$ ) with comparison of carbon free market price and regulated Market - CDM

\begin{tabular}{ll}
\hline \multicolumn{2}{c}{ Nilai Rerata } \\
\hline Karbon (Mg C) & 23.397 \\
CO $_{2 \mathrm{e}}$ (Mg) & 85.866 \\
Pasar Bebas (Rp) & 6.955 .123 .566 \\
Pasar wajib CDM (Rp) & 18.176 .056 .252 \\
\hline
\end{tabular}
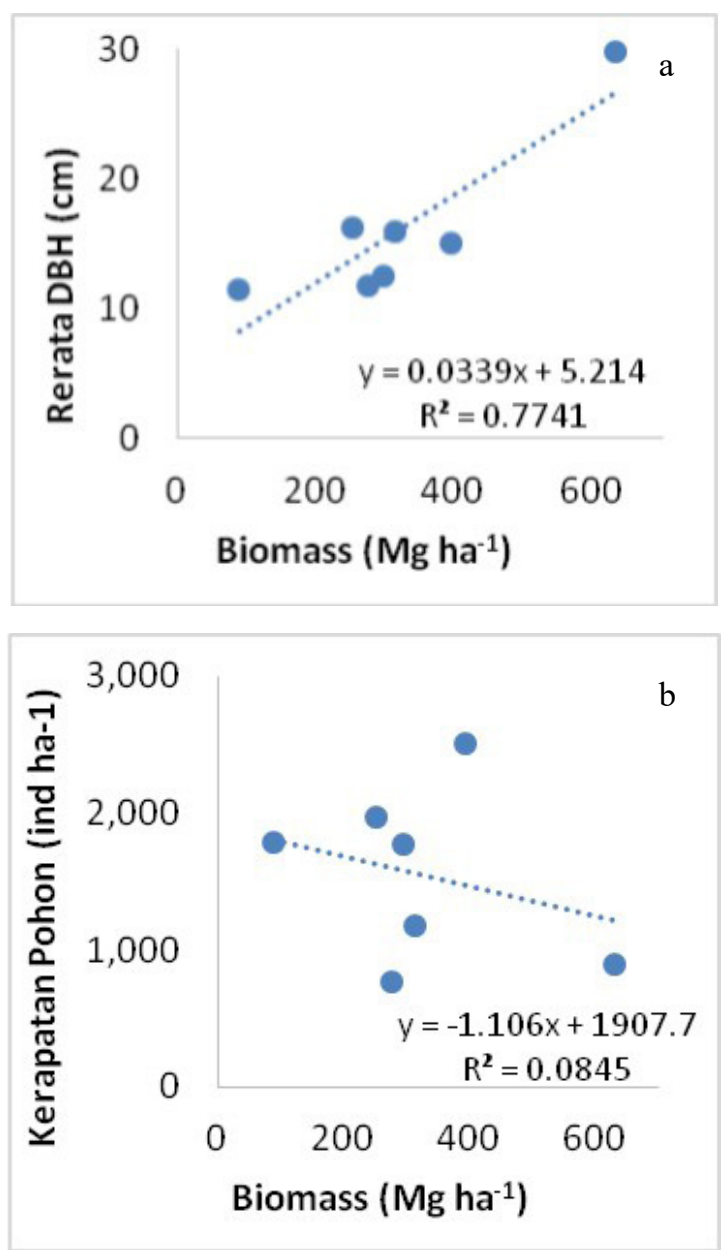

Gambar 4. Hubungan antara kepadatan pohon (a) dan DBH (b) dengan biomassa mangrove

Figure 4. The relationship between tree density (a) and $\mathrm{DBH}$ (b) with biomass of mangrove

Nilai ekonomi ekosistem mangrove di Kema sebesar Rp. 6.955.123.566 (pasar bebas) dan Rp. 18.176.056.252 (Clean Development Mechanism) untuk simpanan karbon sebesar 23.397 MgC. Estimasi ekonomi simpanan karbon di ekosistem pesisir lainnya, seperti lahan gambut disepanjang pantai timur Sumatera selatan memiliki kisaran sebesar Rp. 14.002.162.211.645 yang dihitung dari cadangan karbon bagian bawah sebesar 2.677,279 ton $\mathrm{CO}_{2} /$ ha (Ulya et al., 2015).

Hasil analisis ini memperlihatkan bahwa penyimpanan karbon sebagai salah satu jasa ekosistem yang belum banyak diperhitungkan ternyata turut menyumbang nilai ekonomi yang cukup besar dan tidak kalah dengan sumbangan nilai ekonomi jasa ekosistem lainnya. Apabila kemampuan penyimpanan karbon ini turut diperhitungkan maka tentunya akan menambah nilai jasa ekosistem yang selama ini telah dilakukan terkait dengan sumberdaya hayati dan kemampuan mangrove dalam mereduksi gelombang. 


\section{KESIMPULAN DAN SARAN}

Ekosistem mangrove di Kecamatan Kema secara umum masih berada pada kondisi baik, dimana beberapa stasiun memiliki vegetasi yang padat dengan diameter yang besar. Kondisi ini dapat memberikan informasi bahwa ekosistem mangrove di Kema masih dapat berperan secara ekologis sebagai ruang hidup berbagai biota, sumber nutrien serta jasa eosistem lainnya termasuk penyimpanan karbon. Terdapat delapan spesies mangrove, dimana $S$. alba dan $R$. mucronata memiliki nilai penting yang lebih tinggi dibandingkan dengan spesies yang lain. Estimasi simpanan karbon pada vegetasi mangrove berkisar antara 38,32 - 261,85 $\mathrm{MgCha}^{-1}$ dengan nilai rerata sebesar $133,76 \pm 25,70$ $\mathrm{MgCha}^{-1}$. Nilai tersebut berada pada kisaran menengah apabila dibandingkan dengan informasi simpanan karbon dari beberapa tipe ekosistem mangrove di Indonesia. Simpanan karbon vegetasi memiliki nilai ekonomi yang tinggi dengan nilai lebih dari 18 milyar rupiah. Nilai ekologi dan ekonomi ekosistem mangrove di Kema yang dihasilkan dari penelitian ini, dapat dijadikan sebagai informasi awal perumusan kebijakan pengelolaan ekosistem mangrove secara lestari dan berkelanjutan.

\section{DAFTAR PUSTAKA}

Alongi, D.M. (2014). Carbon Cycling and Storage in Mangrove Forests. Annual Review of Marine Science, 6, pp.195-219.

Alongi, D. M., Murdiyarso, D., Fourqurean, J. W., Kauffman, J. B., Hutahaean, A., Crooks, S., Lovelock, C. E., Howard, J., Herr, D., Fortes, M., Pidgeon, E., \& Wagey, T. (2015). Indonesia's Blue Carbon: A Globally Significant and Vulnerable Sink for Seagrass and Mangrove Carbon. Wetlands Ecology and Management.

Ati, R. N. A., Rustam, A., Kepel, T. L., Sudirman, N., Kusumaningtyas, M. A., Daulat, A., Mangindaan, P., Salim, H. L., \& Hutahaean, A. A. (2014). Stok Karbon dan Struktur Komunitas Mangrove Sebagai Blue Carbon di Tanjung Lesung, Banten. Jurnal Segara, Vol. 10, No. 2: 98-171.

Bengen, D. G. (2003). Pedoman Teknis Pengenalan dan Pengelolaan Ekosistem Mangrove. PKSPL. Bogor.

Bouillon, S., Borges, A. V., Castaneda-Moya, E., Diele, K., Dittmar, T., \& Duke, N.C. (2008). Mangrove Production and Carbon Sinks: A Revision of Global Budget Estimates. Global Biogeochemical Cycles, 22(2).

Cahyaningrum, S.T., Hartoko, A., \& Suryanti. (2014). Biomassa Karbon Mangrove pada Kawasan Mangrove Pulau Kemujan Taman Nasional Karimunjawa Mangrove. Diponegoro Journal of
Maquares, Vol. 3, No.3 : 34-42.

Duke, N., Kathiresan, K., Salmo III, S. G., Fernando, E. S., Peras, J.R., Sukardjo, S., \& Miyagi, T. (2010). Ceriops tagal. The IUCN Red List of Threatened Spesies 2010: e.T178822A7617531.

Ellison, J., Koedam, N.E., Wang, Y., Primavera, J., Jin Eong, O., Wan-Hong Yong, J., \& Ngoc Nam, V. (2010). Lumnitzera littorea. The IUCN Red List of Threatened Spesies 2010: e.T178854A7628170.

Gren, I. M. (2015). Estimating Values of Carbon Sequestration and Nutrient Recycling in Forests: An Application to The Stockholm-Mälar Region in Sweden. Forests 2015, 6, 3594-3613. ISSN 19994907.

Hartoko, A., Cahyaningrum, S., Febrianti, D. A., Ariyanto , D., \& Suryanti. (2015). Carbon Biomass Algorithms Development for Mangrove Vegetation in Kemujan, Parang Island Karimunjawa National Park and Demak Coastal Area - Indonesia. Procedia Environmental Sciences, Basic Researches in The Tropical and Coastal Region Eco Developments. Vol. 23:39-47.

Howard, J., Hoyt, S., Isensee, K., Telszewski, M., \& Pidgeon E, eds. (2014). Coastal Blue Carbon: Methods for Assessing Carbon Stocks and Emissions Factors in Mangroves, Tidal Salt Marshes, and Seagrasses. Conservational International, Intergovernmental Oceanographic Commission of UNESCO, International Union for Conservation of Nature, Arlington.

Kauffman, J.B., \& D.D. (2012). Protocols for The Measurement, Monitoring and Reporting of Structure, Biomass and Carbon Stocks in Mangrove Forests. , Working Pa, p.50.

Murdiyarso, D., Purbopuspito, J., Kauffman, J. B., Warren, M. W., Sasmito, S. D., Donato, D. C., Manuri, S., Krisnawati, H., Taberima, S., \& Kurnianto, S. (2015). The Potential of Indonesian Mangrove Forests for Global Climate Change Mitigation. Nature Climate Change, (July), pp.8-11.

Nahib, I. (2011). Pemetaan Valuasi Ekonomi Hutan Mangrove Berdasarkan GIS dan Metode Benefit Transfer : Studi Kasus Hutan Mangrove di Wilayah ALKI II. Globë Volume 13 No 1 : 31 - 40.

Pendleton, L., Donato, D. C., Murray, B. C., Crooks, S., Jenkins, W. A., Sifleet, S., Craft, C., Fourqurean, J. W., Kauffman, J. B., Marba, N., Megonigal, P., Pidgeon, E., Herr, D., Gordon, D., \& Baldera, A. (2012). Estimating Global "Blue Carbon" Emission from Conversion and Degradation of Vegetated Coastal Ecosystems. Plos ONE 7(9):e43542.

Pramudji. (2004). Mangrove di Pesisir Delta mahakam Kalimantan Timur. Pusat Penelitian OceanografiLIPI, Jakarta.

Siikamäki, J., Sanchirico, J. N., Jardine, S., McLaughlin, D., \& Morris, D. (2013). Blue Carbon: Coastal Ecosystems, Their Carbon Storage, and Potential for Reducing Emissions Environ.: Sci. Policy Sustainable 
Dev. 55 14-29

Saprudin \& Halidah. (2012). Potensi dan Nilai Manfaat Jasa Lingkungan Hutan Mangrove di Kabupaten Sinjai Sulawesi Selatan. Jurnal Penelitian Hutan dan Konservasi Alam, Vol. 9 No. 3 : 213-219.

Sutaryo, D. (2009). Penghitungan Biomassa (Sebuah Pengantar Untuk Studi Karbon dan Perdagangan Karbon), Wetlands International Indonesia Programme, Bogor.

Suzana, B. O. L., Timban, J., Kaunang, R., \& Ahmad, F. (2011). Valuasi Ekonomi Sumberdaya Hutan Mangrove di Desa Palaes Kecamatan Likupang Barat Kabupaten Minahasa Utara. ASE Vol. 7 No. 2: 29-38.

Ullman, R., Bilbao-Bastida, V., \& Grimsditch, G. (2013). Including Blue Carbon in climate market mechanisms. Ocean \& Coastal Management, Vol. 83 : 15-18.

Ulya, N. A., Warsito, S. P., Andayani, W., \& Gunawan, T. (2015). Nilai Ekonomi Karbon Hutan Rawa Gambut Merang Kepayang, Propinsi Sumatera Selatan. Jurnal Manusia dan Lingkungan, Vol. 22 No. 1: 52-58. 